\title{
Private Rental Housing in the Czech Republic: Growth and...?*
}

\author{
MARTIN LUX and PETR SUNEGA** \\ Institute of Sociology, Academy of Sciences of the Czech Republic, Prague
}

\begin{abstract}
The goal of this article is to describe the development of private rental housing after 1990 in the Czech Republic and especially to demonstrate the significance of state regulations on people's expectations, social norms, and thus the form of housing systems emerging in transition countries. The argument of this article is that state interventions affecting property restitution, the protection of tenants, rent regulation, and the relative subsidisation of individual housing tenures are crucial factors influencing the perception and significance of private renting in the Czech Republic. At the beginning of the transition there was a universe of options: the private rental sector could evolve into a stable and significant tenure or into a weak, volatile, and residual type of housing. The particular rules of the game - state regulations - led to the quick supply of new private rental dwellings, but at the same time they substantially constrained the long-term demand for this type of housing. Like in those advanced countries where a more dramatic form of private rental housing liberalisation occurred, in the Czech Republic the significance of rental housing quickly shifted to become a temporary and residual form of housing. This article is thus about the 'greenfield' establishment of a housing system and how initial state regulations create or modify the long-term social norms relating to housing tenures and especially to private rental housing tenure.
\end{abstract}

Keywords: Czech Republic, housing system, private rental housing, transition economies, housing theory

Sociologický časopis/Czech Sociological Review, 2010, Vol. 46, No. 3: 349-373

\section{Introduction}

The most common categories of housing tenure are rental housing and owner occupancy. Research and policy practice in advanced countries distinguish also two subcategories of rental housing according to the form of provision: social rental housing and private rental housing. Social rental housing is typically allocated

\footnotetext{
* Research for this article was made possible with the support of the Grant Agency of the Czech Republic, grant no. 403/09/1915.

** Direct all correspondence to: Martin Lux, Institute of Sociology, Academy of Sciences of the Czech Republic, Jilská 1, 11000 Prague 1, Czech Republic, e-mail: Martin.Lux@soc.cas. cz; Petr Sunega, Institute of Sociology, Academy of Sciences of the Czech Republic, Jilská 1, 11000 Prague 1, Czech Republic, e-mail: Petr.Sunega@soc.cas.cz.
}

C Sociologický ústav AV ČR, v.v.i., Praha 2010 
according to need (it targets low-income or other needy households), while market forces play a crucial part in the allocation process of private rental housing [Haffner et al. 2009]. Social housing landlords are typically public or non-profit organisations (with exceptions), while private landlords are mostly for-profit, physical and legal entities (small and professional investors). Since the late 1970s the explicit goals of housing policies in many advanced countries have been to strengthen the significance of the private rental sector. States have been attempting to create conditions to 'resuscitate' private renting after several decades of a decline induced by post-war rent regulations. The motives for this endeavour included, for example, the need to cut public housing expenditures, increase labour flexibility, and return market logic to the sector of housing.

After 1990 the housing tenure structure in post-socialist countries changed dramatically, at least in formal terms. The sharp decrease in the share of public rental housing was offset by an increase in the share of owner-occupied housing [Lux 2003; Donner 2006; Lowe and Tsenkova 2003; Struyk 1996; Hegedüs and Tosics 1998]. The reason for this was the large-scale give-away privatisation of public rental flats to the ownership of sitting tenants. The massive transfer of real estate from public to private ownership created good conditions for the emergence of private renting. Moreover, in a few of these countries, the Czech Republic being one of them, property (including apartment buildings) that had been confiscated by the socialist regime was restituted (returned) to the original owners or their heirs. One of the objectives of restitution was to restore the stock of private rental housing (PRS) and thus re-establish continuity with the pre-socialist housing system [Lux et al. 2005]. Alongside restitution, changes, at least to some extent, were made to the rent control regimes.

The goal of this article is not only to describe the development of the PRS during the two decades of transition in the Czech Republic, but also and above all to demonstrate the impact of state regulation on people's expectations and social norms relating to this particular housing tenure. We argue that state interventions affecting property restitution, tenant protection (tenure security), and rent regulation are crucial factors that have had an influence on the demand for private renting and thus the long-term meaning ascribed to the PRS in the Czech Republic. At the start of the transition there was a whole universe of options - the PRS could become a stable and significant tenure (like in Germany) or it could become a weak, volatile, and residual type of housing (like in Belgium). The future was in the hands of those who were participating in the discourse about the new rules of the game. These rules, consequently, shaped the meaning of the PRS. This article is about how regulations (new rules) reflecting the results from politically driven discourse create or modify the social norms attached to one particular housing tenure - private renting.

The article opens with a rough review of the regulations affecting the PRS in advanced countries. In this section, the theoretical framework used to explain the differences in housing systems is briefly discussed. The next section provides 
a description of the main relevant contextual factors - especially the regulations - that were essential to the development of the PRS in the Czech Republic. The information presented in that section relates to the restitution of the housing stock, rent regulation, social inequalities in access to rental housing, and the consequent segmentation of the rental housing market. The third section of the article describes the development of the PRS itself, in particular the scope of new investments in the PRS, the trend in market rents in relation to the trend in house prices, the social composition of PRS tenants and the structure of the PRS housing fund. In the closing section, against the background of findings from the context analyses and using a wide range of attitude surveys, we focus on estimating the possible future of the PRS in the Czech Republic.

\section{The international context - the regulations affecting the PRS}

The change in the direction of macro-economic and housing policies in Western developed countries since the late 1970s [e.g. Boelhouwer and van der Heijden 1992; Oxley and Smith 1996; Barlow and Duncan 1994] has in part involved a gradual shift away from the 'first-generation' type of strict post-war rent regulation in the PRS [Arnott 1995; Lind 2001]: the process of rent deregulation led either to the introduction of a more market-friendly, 'second-generation' rent regulation regime (in most countries) or to almost total liberalisation of private rents (for instance, in the UK, Finland) [e.g. Donner 2000; Lind 2001; Giorgi, Kofler and Avramov 2001]. Together with the shift away from direct housing supply subsidisation (so-called brick-and-mortar subsidies) towards indirect housing demand subsidies, the process of rent deregulation was logically meant to lead to a more substantial revival of private rental housing. However, but for some exceptions (Germany and in the last few years the UK), this did not occur [Haffner, Elsinga and Hoekstra 2008]. The share of private rental housing in the total housing stock of the country usually just stabilised and did not shrink any further (e.g. in France and Spain it remains today at the same level it was at in the 1980s).

In the UK, the EU country that took the most dramatic steps to liberalise the regulation of the PRS, the share of the PRS increased only from $9 \%$ to $10 \%$ of the total housing stock in the twelve years between 1988, when the PRS deregulation started (with the introduction of the 'assured shorthold tenancy'), and 2000 (Department for Communities and Local Government ${ }^{1}$ ). In 2001 the trend began to change (and even more so after 2004), and in the subsequent eight years (until 2008) the share of the PRS increased to almost $14 \%$ of the housing stock. This growth has probably been influenced by the introduction of so-called buy-to-let mortgages on the supply side of the market and by massive foreign labour immigration from the new EU member states on the demand side of the market.

\footnotetext{
${ }^{1}$ http://www.communities.gov.uk/housing/housingresearch/housingstatistics/housingstatisticsby/.
} 
Although some British authors have described this trend as a 'boom' or 'substantial growth' [Hughes and Lowe 2007], the end of the global economic crisis will show whether this increase is just short term or whether it is sustainable in the long term. Haffner, Elsinga and Hoekstra [2008] showed that out of the countries observed in their study (Germany, France, Netherlands, Spain, Sweden, and the UK) a substantial increase in the share of rental housing in the past decade occurred only in Germany (partly as a result of German reunification). Moreover, Germany has long had the largest share of rental housing - even today more than $35 \%$ of German households live in the PRS.

A complicated question is why private rental housing did not experience a general resuscitation? Was it owing to the lack of interest from investors, or to the weak demand for this type of housing?

The character of the PRS is and in the future will probably continue to be different in most advanced countries than what it was in the 1940s [Oxley and Smith 1996; Rugg and Rhodes 2008; Rugg 1999; Hughes and Lowe 2002]. With some exceptions (Germany, Switzerland), private rental housing has ceased to be a form of housing for life, and in most countries it has instead become a form of temporary (transitional) housing for young people and of more permanent residual housing only for households that cannot afford to buy their own housing, owing to their low income or to discrimination in the housing market. This change in the character of the PRS was connected with the rocket increase in the turnover of PRS tenants and the substantial drop in the average age of PRS tenants (on the UK, see Hughes and Lowe [2002]).

What brought about this change was not so much state intervention leading to a decrease in the attractiveness of this sector for private capital, but rather the deregulation of mortgage financing and the fall in inflation (interest rates). Mortgage credit and, consequently, owner-occupied housing became accessible to a much wider segment of households than ever before. On the other hand, the increased affordability of owner-occupied housing cannot alone be responsible for the 'stagnation' (or the just mild or slow increase) of the share of the PRS in most advanced European countries in the past two decades, the substantial increase in the turnover of PRS tenants (and, consequently, in the short-term vacancy rate), and the transformation of the PRS into just a transitional and/or residual form of housing.

The number of singles or unmarried and childless couples who require various sorts of flexible housing is growing [Rugg 1999; Ford, Rugg and Burrows 2002]; the age at which people start a family has generally risen significantly. In most advanced OECD countries house prices rose faster than household incomes until 2007 (according to the OECD price-to-income indices) and income inequalities have also been on the rise over the past two decades. Consequently, the number of households that has difficulty with gaining access to owner-occupied housing could not have decreased very much, despite the increasing affordability of mortgage financing. Also, states significantly cut back on their support for social housing and conversely increased support in the form of a housing al- 
lowance, to which tenants are entitled regardless of whether they live in social or private rental housing [Oxley and Smith 1996; Barlow and Duncan 1994; Donner 2000; Kemp 2007]. So there are probably other structural reasons for why there was no general resuscitation of the PRS in most advanced countries; other factors behind the fact that the PRS did not grow or did not become a real alternative to owner-occupied housing. Sociological theories applied in housing policy research may help somewhat to identify these reasons.

Political structuralism stresses the role that ideology and the interests of specific political parties, or more importantly the process of political decisionmaking itself, influenced or directed by powerful interest groups behind political structures, may play in shaping and developing state policies. Lundqvist [1992] applied this theory to housing policies and focused mainly on the actual distribution of political power, that is, on who was recently in power - whether it was political parties with related bureaucracy and interest groups having a market-weak position or political parties with related bureaucracy and interest groups having a market-strong position. Market-weak parties promote non-market solutions, such as stronger state intervention in the housing market (public housing investment), while market-strong parties promote market solutions (private housing investments). However, Boelhouwer and van der Heijden [1993] challenged his theory by showing the weak correlation between the type of political party in power and housing policies in six developed European countries. As mentioned above, the process of increasing the importance of owner-occupied housing is long term and it does not reflect the relatively frequent rotation of left-wing and right-wing political parties in power in advanced countries.

The sociological concept of social constructivism [Berger and Luckmann 1966] postulates that social reality is socially constructed; such social reality relates not just to 'soft categories' like ideology, norms, ethics, and national 'myths', but also to such institutions as markets, money, government, and housing tenure. Repeated reciprocal interactions between individuals are institutionalised and in the process of such institutionalisation the meaning of social facts becomes embedded in a society. The meaning of a social fact is thus subject to discussion, manipulation, and political struggle. There is no true, 'objective' essence; neither just one right way, nor one true meaning. The only reality is the battle between the competing meanings ascribed to social facts by the conflicting interests of particular social groups. Social norms are subject to change, but given the fact that this is a path-dependent historical process this change (the institutionalisation of new interactions) is only rarely dramatic. Despite the continuous battle between competing meanings and despite the fact that the formal rules of the game can be changed relatively quickly, once internalised the implicit social norms of a specific society (cultural patterns) change only gradually and they are, therefore, relatively stable even in the long term.

The role of social norms in the development of a housing system (and especially its tenure structure) has been noted in several studies by Kemeny. Kemeny [1981, 1992, 1995] looked at the wider social arrangements and ideological dispo- 
sitions in various countries rather than the particular configuration of political power. His main emphasis is on the meanings (ideas, norms) assigned to reality but these social norms cannot be altered by any temporary political representation; they are stable and long term in character. Kemeny [1981] distinguished two general types of housing system: home-owning and cost-rental. Using data on several industrialised countries he concluded that there has been an important divergence between countries according to the prevailing social ideologies (reflected in their social policies) - whether it be collectivism or privatism. Such an ideological framework has an effect on 'political tenure strategy'. Governments that pursue a particular social ideology create environments that favour one or another type of tenure and influence the tenure decisions of its citizens.

Kemeny [1995] then distinguished housing policy models as dualist (stigmatising one type of tenure, namely tenancy, and unilaterally supporting one type of tenure, namely owner-occupancy) and unitary (tenure neutral), and made a somewhat normative judgement about the causes of divergence - while the dualist model aims to protect the private and the for-profit sector, the unitary model ensures that the housing system as a whole meets general welfare goals. Kemeny's typology was based on identifying the so-called 'maturation process'. The historical (and thus lower than contemporary) acquisition costs mean that a mature stock of dwellings can be rented for rents that are lower than the current market rents. Governments can decide whether the benefits from the maturation process will be passed on to tenants (the unitary model) or whether they will be passed on to private individuals (the dualist model). The dualist model is especially associated with the type of policy that discourages cost-renting (social housing) and develops it only as a safety net 'to take care of those who become the casualties of the workings of the profit market' [Kemeny 1995: 9]. Unitary models, by contrast, encourage cost-renting, allowing it to compete with the private sector.

However, even his theory has, alongside several normative connotations, ${ }^{2}$ one important drawback and thus cannot be fully applied in our analysis. In his generalised approach, Kemeny suspends more detailed contextual differences within rental housing that seem to be very important for a housing policy typology, and especially with respect to the main goal of this paper. He generally refuses to regard the PRS and non-profit social rental housing as two separate housing tenures, even though since the late 1970s private rental housing in many

\footnotetext{
${ }^{2}$ Kemeny, for example, mentions several disadvantages of the dualist model, such as the high volatility of housing production and the residualisation of cost-renting. However, he pays no attention to the drawbacks of the unitary model, such as the bureaucratic procedures involved in the allocation of cost-rental housing, the long waiting lists, the manipulation of housing preferences as a result of the existence of low-rent housing, the migration barriers, the danger of the political abuse of the allocation mechanism and the mismanagement of housing production, which often results in the construction of unattractive pre-fab apartments - this housing ultimately may become a residual type of housing in the same sense as public housing does in the dualist models.
} 
advanced countries has become more a part of the profit-driven market and thus, by his way of thinking, has become more like owner-occupied housing and less like cost-renting. According to Kemeny, profit market policies (the dualist model) favour owner-occupation, and cost-renting policies (the unitary model) do not favour any tenure and encourage cost-renting to compete with for-profit private renting. The type of policy that does not favour any tenure, but, at the same time, does not encourage cost-renting to compete directly with the private sector and instead respects the market principles in rental housing (Germany, Switzerland) occupies a 'middle' place in his typology and represents a half-profit, half-cost (half-unitary, half-dualist) hybrid.

However, this type of policy is very specific, and it lies outside the scope of his dualistic perspective, rather than figuring somewhere in between the two extreme policy models. It is a tenure-neutral policy, but, at the same time, it does not encourage state interventions to expand the cost- (public) rental housing segment so that it directly competes with the private sector. Its aim is not to dampen rent levels and in the long run eliminate for-profit renting through what Kemeny calls 'competition' (i.e. competition with state-subsidised non-profit renting), but rather to ensure the functioning of the housing market (including adequate profit to private landlords) and keep tenure choice unbiased. Its purpose is not to ameliorate the profits of private market actors as much as possible by encouraging non-profit forms [Kemeny 1995: 49-50], but to ensure the efficient functioning of markets (competition between small market actors), in which investors cannot make short-term, abnormally high profits owing to market imperfections and in which their investments also serve the welfare goals of society.

Kemeny's understanding of the social market concept and, by extension, the tenure-neutral unitary policy model cannot be applied to the housing systems in Germany or Switzerland (despite the fact that he does so partially), that is, to the countries with the most stable private renting sector in Europe. The process of maturation leading to low historically-based rents (assigned by Kemeny to the tenure-neutral unitary policy model) can be applied only to non-profit schemes because private investors, including those in Germany or Switzerland, calculate their yields based not on historical but on actual house prices. In other words, the private investor always has two options: sell the flat and use the money for some other form of investment that gives a higher yield with the same risk, or rent the flat. This means that sufficient profit from renting the flat must be calculated on the basis of the actual (not the historical) value of the flat, because if the flat were vacant the private landlord would always have the option of selling it and using the capital for alternative investments. If the direct competition from the nonprofit cost-rental segment did not reflect this aspect of private investor choice, the private for-profit rental segment would decline in the long term. Instead, we find that in Germany the share of for-profit private rental housing tenure was growing (and it did not follow the decline known, for example, from Denmark). Kemeny suspends this economic rationing and generally downgrades the significance of the factors of economic efficiency and specific rent regulations. Consequently, he 
cannot, for example, explain the important contextual differences between Denmark and Germany.

We believe the difference between private rental and cost- (social) rental housing to be significant; we see them as two very distinct housing tenures. We also see a specific - and from Kemeny's typology missing - type of policy that is known for Germany and Switzerland, that is, for countries with the largest share of PRS in Europe. Although it is tenure-neutral, this policy does not encourage non-profit schemes to compete directly with the for-profit market segment. Instead, it encourages for-profit investors to satisfy welfare needs and it regulates the market with the sole aim of increasing its efficiency (competitiveness) and stability (reducing volatility, eliminating market shocks). Therefore, Kemeny's dualistic typology cannot distinguish important contextual differences within a group of countries with what he calls a unitary policy model because it does not take into account the specific regulations applied to the rental housing in different societies. With respect to the main goal of this article, we, therefore, do not see the main difference between policy systems as lying in the social norms that favour one tenure over another (as both German and Danish policies are tenureneutral), but rather in the social norms that favour a specific type of regulation of the PRS (as these regulation systems are different) and especially a specific type of regulation of rent in the PRS.

Rental housing reforms mentioned above involved transforming the rigid post-war system of 'first-generation' rent regulation into a 'second-generation' system of rent regulation. What is the basic difference? Lind [2001] claims that it is possible to define a first-generation rent regulation regime with the following three characteristics:

- Nominal rent freezes;

- The kind of trend in nominal rent that leads to a decrease in real rent;

- The kind of trend in nominal rent that leads to a decrease in real rent or leaves nominal rent well below the level of market rent.

'Second-generation rent control is any regulation of the rental market that does not fulfil definition above. There is no nominal rent freeze, rents do not usually fall in real terms and in the long run there might be no significant difference between actual rents and market rents.' [Lind 2001: 43] Although the transition to a second-generation rent regulation regime was relatively universal in the advanced part of the EU, a huge variety of approaches were applied in this process [e.g. Lind 2001; Haffner, Elsinga and Hoekstra 2008; Donner 2000]. Extreme liberal systems of second-generation rent regulation essentially set no direct limits on the level of initial rent and subsequent rent reviews (the UK, Ireland, de facto Belgium, Finland). Moderate systems limit rent regulation exclusively to running leases, while for newly signed leases rents can be set freely (Germany, Switzerland, Spain). In stricter systems not just the rents for running leases but also a substantial portion of newly signed leases are regulated (Netherlands - the initial rent must be in an interval set according to particular 'qualitative points', and only flats 
with high rents are excluded from this restriction; France - the rent for newly signed leases is unrestricted only if the flats are newly built or renovated, while the initial rents for 'older' flats are determined by a local reference-rent system). In the strictest systems rents are regulated for all running and newly signed leases (Sweden - rent for privately owned flats can be no more than $5 \%$ higher than the reference rent for municipal flats, which is determined by agreement between the municipalities and tenant associations; Denmark - rent for privately owned flats can be no more than 10-15\% above a 'reasonable' rent level, which is defined as cost rent and also encompasses a 'commensurate' amount of profit).

Rent reviews for running leases are constrained by a maximum rent level according to the dwelling 'quality' (Netherlands), by a maximum rent level agreed between the municipalities and tenant representatives (Sweden), by a referential rent index (France, calculated on the basis of an aggregate index composed of the Consumer Price Index, the index of maintenance and renovation costs, and the index of construction costs), by the Consumer Price Index (in Spain, during the first five years of a lease; in Belgium, during the first three years of a lease), by a maximum 'commensurate' level of profit (Switzerland), or by the level of local reference rents (in Germany, this is determined by a court or by so-called rent maps). Such constraints are sometimes accompanied by the condition that shock rent hikes are not allowed (for example, in Germany, rent cannot be increased by more than $20 \%$ over the course of three consecutive years). Lease durations are also regulated: in Germany, Switzerland, and Denmark landlords can only (with some exceptions) sign open-term leases, in France a lease must be for a minimum term of three years (for landlords-physical persons) or six years (for institutional landlords), in Spain for five years, in Belgium for three years (but exceptionally also for a shorter period, and this exception allegedly applies to the main share of leases signed), in Portugal for three years, and in the UK for six months.

The Swedish, Danish, and to some extent also the Dutch and French systems of second-generation rent regulation may contribute to the existence of big risks for private investors. This fact could hypothetically be one of the reasons behind the stagnation or decline in the significance of the PRS in these countries. Conversely, in some countries with the extreme liberal system of second-generation rent regulation (Finland, and since 2001 the UK) the share of private rental housing grew. However, the long-term stabilisation of the PRS is not observed in countries with the most liberal system of rent regulation (examples are the stagnation of this segment in Ireland, the decline in Belgium, or the delayed growth in the UK), but rather in a country with a moderate system of second-generation rent regulation and stronger protection of the duration of a lease (Germany). Although there is no straightforward and verified answer to why the PRS has failed to take hold in the past two decades, the simple comparison of state regulations applied to the PRS in selected advanced countries briefly sketched above suggests that forms of regulation may hypothetically have an important influence on the size and significance of the PRS. From this perspective, the following reasons 
can theoretically be seen as the source of the 'failure' of the PRS in most advanced European countries:

- An inappropriate second-generation regime of rent regulation, which too strictly limits the rent yields or one-sidedly protects the interests of tenants - a system that continues to put off investors from investing in residential real estate - this may be the case for the Netherlands or Sweden;

- The extensive liberalisation of rents and the excessive reduction of tenant protections, which results in tenants of private flats being subjected to unsustainable risks, both in terms of lease durations and future rent reviews - this adds to the view of private rental housing as just a temporary, residual, uncertain and unpopular form of housing; this may be the case for Ireland and Belgium (and to some extent also the UK).

The regulatory system - legislative tenant protections and rent regulation - may hypothetically have a fundamental impact on determining the meaning of the PRS in various socio-cultural environments. However, on the whole there is little research on the influence of institutional structures (regulations) on demand for the PRS in advanced countries, partly because of the difficulties with empirical verification, which would require statistically controlling for the influence of many other institutional and cultural factors that began gradually to evolve many decades ago. We can better verify this hypothetical relationship, though again just partly, using the case of a transition country, where the influence of the past, though still important, is weaker and new system elements are thus less shaped by path dependence and traditions.

The transition countries started their new democratic histories after 1990 with de facto zero private renting stock and the perceptions and expectations attached to this tenure were not as strongly influenced by history, past stigmatisation, cultural values, and social norms. Private renting was able to start with a 'blank slate' and could develop into a number of very different forms: it could become a form of stable life-long housing, like the system in Germany, or it could become a form of residual, transitional housing, like the systems in liberal countries such as the UK and Belgium. Our hypothesis about the relationship between the specific form of regulation and the meaning of the PRS can, therefore, be better tested through the case of transition countries and specifically the Czech Republic.

\section{The context of the Czech Republic}

From the very founding of Czechoslovakia (1918) there has been some form of regulation of the housing market (as in other countries in Europe). Regulation involved rent control and restrictions applied to the leases signed between landlords and tenants, the purpose of which was to benefit certain individuals defined by the municipalities; the protection of tenants included also protection against groundless eviction [Mildschuh 1931; Kratoška 1920]. However, later rent controls 
were gradually slackened, so that after 1920 there was no rent control in buildings built after 27 January 1917, and protections were gradually withdrawn from other categories of tenants (e.g. tenants in large flats, high-income households, tenants in flats located in municipalities with fewer than 2000 inhabitants and where no more than one-third of the total housing stock was comprised of rental flats). The construction boom that occurred early after that was driven mainly by private investors in residential rental buildings [Poláková 2006]. Following the Munich Agreement (1938) and Germany's annexation of the border regions of Czechoslovakia the construction of private rental housing ground to a halt.

After 1948 Czechoslovakia's economy shifted to central planning and housing construction began to be centrally controlled by the state. Most private residential buildings, built during the boom between 1920 and 1938, were expropriated and became the property of the state. State rental housing gradually became the dominant tenure in urban centres. The key principle of housing policy was to allot flats for free 'according to people's needs' and the level of rent was set very low, so the costs of maintaining and regenerating the housing stock had to be subsidised from the state budget. For example, the level of rent remained unchanged from 1964 up until the collapse of socialism in 1990. Tenants who were allotted flats by the state obtained unlimited occupancy rights in the form of a so-called 'deed' to the flat. No one spoke about 'renting', but about the 'personal use' of a flat. 'Personal use' became an institution separate from that of rental tenure - it could be inherited or transferred to relatives, or exchanged with some other holders of user rights. The tenants arrogated the right to renovate and repair the flat according to their will and without the owner's permission, or even to sublease the flat without the owner's permission; when flats of different implicit values were exchanged, people appropriated the right to request financial compensation following from unequal exchange for themselves - all this was later called quasiownership of housing [Šmídová 1996].

After the political changes in 1990, the first step in the transformation that affected housing was the restitution of the housing stock. The process of property restitution began in April 1991 and it applied to that part of the housing stock that was expropriated between February 1948 and January 1990. According to the legislation, the original owner or his/her heirs were the persons entitled to apply for the return of property (restitution in kind). By 1993 most of the property transfers were completed; approximately $6-7 \%$ of the housing stock was affected, though in the centre of Prague, for instance, as much as $70 \%$ of the housing stock was restituted [Sýkora and Simoníčková 1994]. The conviction that 'what was stolen must be returned' was a defining feature of the economic transformation. Restitution became one form of privatisation of state property, and as such it was also a reflection of the general neo-liberal ideology that dominated the start of the economic transformation.

However, unlike the restitution of industrial objects, there was a specific dimension to the restitution of residential buildings: most restituted flats had sitting 
tenants, and their occupancy rights remained unaltered - and inviolable - by the restitution. The state not only left the protections accorded to tenants unaltered, but also preserved the rent regulation in restituted properties (after 1993 'free market' rents were allowed only for new and vacated flats). The gradual increase in regulated rent over the course of the 1990s fell short of the pace of increase in the costs of maintaining and regenerating flats. Deregulation of controlled rents started in 1992 allowing landlords to introduce a one-time, 100\% rent increase. In the following years the maximum regulated rent was set in relevant government decrees. However, since 1999 the maximum ceased rising in real terms and since 2002 also in nominal terms (a decrease in real regulated rents occurred). The process of rent deregulation was not restarted until 2007. Yet the state did not offer restituents any form of financial compensation, and this put them at a disadvantage in the landlord-tenant relationship. This segment of rental housing retained the same status it had in the socialist period, a status defined as 'quasiownership', wherein most of the disposal rights attached to the flat were still held by someone other than the actual owner. Private landlords consequently used the phrase 'fictitious restitution' [Filer, Rychetský and Strapec 1995], as they did not regain their ownership rights in full.

The restitution of flats not only gave rise to the new roles of private landlord and tenant, it also generated a new landlord-tenant conflict. Tenants in restituted flats found themselves in a position different from that of tenants in flats owned by the state (later transferred to municipal ownership). Although their rents were also regulated, the restitution denied them the opportunity that public tenants later got - to buy their flats at a very advantageous price. Both tenants and private landlords could be left feeling aggrieved as a result of the way the restitution process was set up and owing to medialisation of these conflicts the PRS came to be associated with problems, insecurity, and tensions. In addition, owing to the slump in public housing construction and the low turnover of tenants in the regulated housing sector, new households were almost unable to find any other housing than in the market sector. The new legislation (introduced in 1993) allowed landlords to charge market rents on all vacant flats (new tenancies) and did not set any limits on initial rent setting, subsequent rent review, or the terms of tenancy. The housing market thus cleaved into two segments: the 'privileged' and 'non-privileged' segments [Lux 2009]. The regulation applied to the 'nonprivileged' segment of rental housing market was similar to the extreme liberal systems of second-generation rent regulation in advanced countries, such as the UK or Belgium.

In the first part of the 1990s, the conditions for the development of the PRS into the form of stable, life-long housing found in Germany were generally very auspicious. In 1990 most of the urban population lived in rental housing - thus, obtaining life-long rental housing 'free-of-charge', without a high debt commitment, was already an established social norm. The restitution of property created private landlords. In 1996, housing allowances were introduced to provide as- 
sistance to low-income tenants. The Czech Republic was not faced with a physical housing shortage - the number of dwellings per 1000 inhabitants was even higher than in some advanced countries. This fact helped to increase the supply of flats from new homeowners (former public tenants) into the PRS. At least at the very beginning of the transition the nostalgia for pre-communist traditions in society was very strong and applied even to the generally positive perception of the role the PRS had played before the communists took power in 1948. The supply-side subsidies connected with centrally planned public housing construction essentially disappeared and market-based housing finance emerged only very gradually. New households were thus faced with a shortage of rental housing. On top of this, given the Czech Republic's close cultural and historical ties with Germany, the cross-border transfer of housing system features could be assumed to be likely. ${ }^{3}$

However, the early Czech governments applied regulations that had nothing in common with the type of tenure-neutral and social market policy found in Germany. Instead of transforming the first-generation rent control regime into a more market-friendly, moderate, second-generation regime, successive governments preserved the first-generation rent control regime (the strictest system of rent regulation) for private restituted properties for many years. Instead of applying a moderate, second-generation regime of rent regulation to new tenancies, the governments chose to apply the extreme liberal system of rent regulation to this segment. Instead of a universal policy towards the PRS as a whole, two extremely different regimes were applied to it. Strict first-generation rent control with openterm contracts and strong tenant protection was at the same time combined with an extremely liberal system of second-generation rent control with no restrictions on the terms of the contract and no effective tenant protection. The rental market became deeply segmented and a variety of tensions and conflicts emerged.

\section{The development of the PRS}

Because there were no limits on setting the initial rents for vacated flats and because early in the transition there was a shortage of rental housing for new households, there soon emerged a large number of small-scale investors in the market offering just one or two flats. The share of PRS out of the total housing stock thus increased very quickly compared to the pace in advanced countries, going from zero in 1990 to $6-7 \%$ in 1993 (as a result of property restitution) and to 12\% in 2001 (in 2009 it may account for an estimated 13-15\% of the total housing stock). Given that each year a certain portion of the regulated segment of the PRS (restituted flats) is freed up, and the new PRS supply after 1993 represented only flats leased for market rents, between 1993 and 2007 the share of flats rented for market rents

\footnotetext{
${ }^{3}$ However, it is necessary to admit that rental housing during socialism had the character of 'quasi-ownership', therefore, it was factually close to owner-occupied housing tenure.
} 
grew from zero to an estimated $50-60 \%$ of the PRS. This trend helped to stabilise market rents.

While the average flat price between 2000 and 2008 increased by almost $200 \%$, the increase in average market rent was much more gradual - it grew only by $64 \%$. The value of the price-to-rent ratio increased, for example, in Prague, between 2000 and 2008, from 13.7 to 26.0, so it almost doubled. This substantially increased the financial appeal of market rental housing for the end user when compared to its main substitute - owner-occupancy. This is also confirmed by a comparison of net market rent and the user costs of owner-occupied housing. The amount of annual net rent is measured against the amount of net user costs of owner-occupied housing - the user costs of owner-occupied housing were calculated in conformity with established practice as the annual interest ${ }^{4}$ costs of buying an average flat (taking into account possible tax savings). ${ }^{5}$ In 2008 , in most regional capitals in the Czech Republic it was for purely financial reasons more advantageous, according to this comparison, to rent than to buy housing. The financial attractiveness of the market segment of the PRS substantially increased, especially thanks to the dynamic growth in the supply of market rental housing.

\section{The household and dwelling characteristics of the PRS}

However, to answer the question about the intrinsic character (meaning) of the PRS, we need to detect the distinct features of the PRS dwellings stock and especially the distinct features of the social structure of the PRS tenants. The goal

\footnotetext{
${ }^{4}$ The interest rate on new mortgages was determined for 2000-2003 from data from the survey 'Mortgage Credit in the Czech Republic' (conducted by the Institute of Sociology AS CR in the middle of 2005); from 2004 the average interest rate of new mortgages published in the system of ARAD of the Czech National Bank is used.

${ }^{5}$ The user costs of owner-occupied housing were calculated with the following formula:

$$
U N_{0}=\left[(1-t)^{*} i+\delta+\alpha-g\right]^{*} P^{e}
$$

where $t$ is the marginal income tax rate (32\% in 2000-2007 and 15\% in 2008), $i$ the nominal interest rate on a mortgage, the rate of depreciation, the property tax rate, $g$ the expected nominal price appreciation of the given real estate in the future, and $P$ the price of a flat. In other words, annual user costs include the average sum of interest paid on the mortgage per year, which is, however, reduced by the possible income-tax deduction of mortgage interest paid. Also calculated into the costs is the estimated payment to the maintenance fund (depreciation) and real estate tax. Deducted from this sum is the expected price appreciation of the real estate. The expected price appreciation of owner-occupied housing (g) was set at $0 \%$, as it is not entirely clear whether Czech households really take price appreciation into account in their decisions (especially in the case of purchasing housing for their own use for a relatively long period). In other words, we assumed that households would buy owner-occupied housing primarily as housing consumption and not as an investment (and thus when making their decision would not be considering the expected price appreciation).
} 
of this section is to show the differences between the PRS and owner-occupied housing tenure (as the main substitute) both in the structure of housing stock and in the social structure of inhabitants. For this purpose we used merged datasets from the EU-SILC surveys 2007 and 2008 - the representative surveys of living conditions using two-level random sampling in each region. The sample consisted of 9675 households in 2007 and 11294 households in 2008; 582 (6\% of all households, 27\% of tenant households) in 2007 and 664 (6\% of all households, $28 \%$ of tenant households) were PRS tenants. The dichotomous character of our dependent variable (tenure choice) led us to apply binary logit models. Altogether, we tested three models:

Model I on dwelling characteristics - PRS versus owner-occupation;

Model II on household characteristics - PRS versus owner-occupation;

Model III on household characteristics - PRS with market rents versus owneroccupation.

We tested for the significance of many independent variables on the differences between both dwelling and household characteristics. It is clear from the tables below that the model with dwelling characteristics as the dependent variable attained much higher explanatory power (Nagelkerke R-square 0.76) than the models with household characteristics as the dependent variable $(0.11$ and 0.15 , respectively).

The model on dwelling characteristics (Model I, Table 1$)^{6}$ selected, alongside regional dummies, the following significant variables from the list of potential factors: rent (continuous; imputed rent for owner-occupation), housing type (apartment and other), number of rooms, and technical standard of the flat - higher rents, fewer rooms, and lower technical standards (problems with humidity, insufficient light, or external noise) are therefore associated with a greater chance that the flat will belong to the PRS. As additional crosstab analysis confirmed, the PRS flats are in worse technical condition than owner-occupied housing. This may be the consequence of property restitution, which affected only the older apartment stock. However, the lower technical conditions can be counterbalanced by better in-urban location (which was not, unfortunately, surveyed by EU-SILC). It is also interesting to see that the PRS is not concentrated in Prague - in the least developed North Bohemia regions (characterised by low salaries, low house prices, and a high unemployment rate) the chance of a flat being part of the PRS is much higher than it is in Prague.

The model on household characteristics (Model II, Table 2) ${ }^{7}$ has much lower explanatory power than the model on dwelling characteristics. The net household income per consumption unit is the statistically significant factor that dis-

\footnotetext{
${ }^{6}$ Nagelkerke R-square 0.765; prediction accuracy 95.9\% (78.6\% for the PRS); dependent variable: 1 - PRS, 0 - owner-occupation.

${ }^{7}$ Nagelkerke R-square 0.110; prediction accuracy $91.3 \%$ (1.6\% for the PRS); dependent variable: 1 - PRS, 0 - owner-occupation.
} 
Table 1. Parameters for logit regression Model I (the model on dwelling structure differences)

\begin{tabular}{|c|c|c|c|c|c|c|}
\hline & B & S.E. & Wald & $\mathrm{df}$ & Sig. & $\operatorname{Exp}(B)$ \\
\hline Rent (imputed rent for OO) & 0.003 & 0.000 & 960.784 & 1 & 0.000 & 1.003 \\
\hline \multicolumn{7}{|l|}{ Other type - ref. } \\
\hline Apartment house & 2.567 & 0.148 & 299.357 & 1 & 0.000 & 13.027 \\
\hline The number of rooms & -1.325 & 0.068 & 384.197 & 1 & 0.000 & 0.266 \\
\hline Humidity & 1.446 & 0.152 & 91.023 & 1 & 0.000 & 4.247 \\
\hline Insufficient light & 0.881 & 0.236 & 14.003 & 1 & 0.000 & 2.414 \\
\hline External noise & 0.257 & 0.137 & 3.528 & 1 & 0.060 & 1.293 \\
\hline \multicolumn{7}{|l|}{ Prague - ref. } \\
\hline Central Bohemia region & 0.520 & 0.263 & 3.916 & 1 & 0.048 & 1.683 \\
\hline South Bohemia region & 1.370 & 0.313 & 19.147 & 1 & 0.000 & 3.937 \\
\hline Plzeň region & 0.807 & 0.278 & 8.422 & 1 & 0.004 & 2.240 \\
\hline Karlovy Vary region & 0.877 & 0.333 & 6.962 & 1 & 0.008 & 2.405 \\
\hline Ústí nad Labem region & 2.404 & 0.235 & 104.275 & 1 & 0.000 & 11.070 \\
\hline Liberec region & 1.682 & 0.295 & 32.495 & 1 & 0.000 & 5.374 \\
\hline Hradec Králové region & 1.329 & 0.295 & 20.294 & 1 & 0.000 & 3.777 \\
\hline Pardubice region & 0.923 & 0.319 & 8.357 & 1 & 0.004 & 2.516 \\
\hline Vysočina region & 1.221 & 0.372 & 10.777 & 1 & 0.001 & 3.391 \\
\hline South Moravia region & 1.167 & 0.268 & 19.001 & 1 & 0.000 & 3.212 \\
\hline Olomouc region & 1.406 & 0.275 & 26.206 & 1 & 0.000 & 4.080 \\
\hline Zlín region & 1.147 & 0.307 & 13.965 & 1 & 0.000 & 3.149 \\
\hline Moravia-Silesia region & 1.861 & 0.230 & 65.633 & 1 & 0.000 & 6.429 \\
\hline Constant & -4.743 & 0.288 & 271.209 & 1 & 0.000 & 0.009 \\
\hline
\end{tabular}

Source: Authors' computation, EU-SILC 2007-2008.

tinguishes PRS tenants from owner-occupiers. Other significant variables are the age of the household head and the type and size of households. The lower the income, the lower the age of the household head, and the smaller the household the greater the chance that a household will live in the PRS. However, the model is too weak to make reliable conclusions.

Model II shows the specific features of the social structure of tenants for the whole PRS. Owing to the segmentation of the PRS into 'privileged' and 'nonprivileged' segments the results can be different when owner-occupation is compared with just the 'non-privileged' market segment of private rental housing. 
Table 2. Parameters for logit regression Model II (the model on household structure differences)

\begin{tabular}{|c|c|c|c|c|c|c|}
\hline & $\mathrm{B}$ & S.E. & Wald & $\mathrm{df}$ & Sig. & $\operatorname{Exp}(B)$ \\
\hline \multicolumn{7}{|l|}{$\begin{array}{l}\text { Low total household income } \\
\text { per consumption unit - ref. }\end{array}$} \\
\hline $\begin{array}{l}\text { Middle total household income } \\
\text { per consumption unit }\end{array}$ & -0.255 & 0.080 & 10.143 & 1 & 0.001 & 0.775 \\
\hline $\begin{array}{l}\text { High total household income } \\
\text { per consumption unit }\end{array}$ & -0.391 & 0.089 & 19.554 & 1 & 0.000 & 0.676 \\
\hline \multicolumn{7}{|l|}{ Two-parent family - ref. } \\
\hline Lone parents & 0.556 & 0.100 & 30.854 & 1 & 0.000 & 1.744 \\
\hline Other type of household & 0.967 & 0.274 & 12.493 & 1 & 0.000 & 2.631 \\
\hline Single - men & 0.766 & 0.129 & 35.405 & 1 & 0.000 & 2.151 \\
\hline Single - women & 0.681 & 0.123 & 30.717 & 1 & 0.000 & 1.976 \\
\hline \multicolumn{7}{|l|}{ Age of head under 34 - ref. } \\
\hline Age of head 35-49 & -0.639 & 0.087 & 54.011 & 1 & 0.000 & 0.528 \\
\hline Age of head 50-64 & -1.204 & 0.096 & 156.252 & 1 & 0.000 & 0.300 \\
\hline Age of head 65 and over & -1.275 & 0.153 & 69.178 & 1 & 0.000 & 0.279 \\
\hline Size of household & -0.205 & 0.045 & 20.404 & 1 & 0.000 & 0.815 \\
\hline \multicolumn{7}{|l|}{ Lower-level employee - ref. } \\
\hline Self-employed & -0.274 & 0.124 & 4.871 & 1 & 0.027 & 0.761 \\
\hline Higher-level employee & -0.035 & 0.085 & 0.165 & 1 & 0.684 & 0.966 \\
\hline $\begin{array}{l}\text { Pensioner with EA household } \\
\text { members }\end{array}$ & -0.613 & 0.249 & 6.056 & 1 & 0.014 & 0.542 \\
\hline $\begin{array}{l}\text { Pensioner without EA } \\
\text { household members }\end{array}$ & -0.485 & 0.142 & 11.674 & 1 & 0.001 & 0.615 \\
\hline Unemployed & 1.035 & 0.156 & 44.215 & 1 & 0.000 & 2.816 \\
\hline Others & 0.568 & 0.215 & 6.968 & 1 & 0.008 & 1.766 \\
\hline Constant & -0.969 & 0.184 & 27.774 & 1 & 0.000 & 0.379 \\
\hline
\end{tabular}

Source: Authors' computation, EU-SILC 2007-2008.

However, as the results of Model $\mathrm{III}^{8}$ show (Table 3), the differences are only minor ones. The most important factor distinguishing the PRS from the owner-occupied segment remains the age of the head of the household.

\footnotetext{
${ }^{8}$ Nagelkerke R-square 0.154 ; prediction accuracy $93.2 \%$ (3.3\% for the PRS); dependent variable: 1 - PRS market, 0 - owner-occupation.
} 
Table 3. Parameters for logit regression Model III (the model on household structure differences, the segment of the PRS with market rents)

\begin{tabular}{|c|c|c|c|c|c|c|}
\hline & $\mathrm{B}$ & S.E. & Wald & $\mathrm{df}$ & Sig. & $\operatorname{Exp}(B)$ \\
\hline \multicolumn{7}{|l|}{$\begin{array}{l}\text { Low total household income } \\
\text { per consumption unit - ref. }\end{array}$} \\
\hline $\begin{array}{l}\text { Middle total household income } \\
\text { per consumption unit }\end{array}$ & -0.520 & 0.085 & 37.307 & 1 & 0.000 & 0.594 \\
\hline $\begin{array}{l}\text { High total household income per } \\
\text { consumption unit }\end{array}$ & -0.666 & 0.091 & 53.787 & 1 & 0.000 & 0.514 \\
\hline \multicolumn{7}{|l|}{ Two-parent family - ref. } \\
\hline Lone parents & 0.087 & 0.108 & 0.654 & 1 & 0.419 & 1.091 \\
\hline Other type of household & 0.618 & 0.286 & 4.673 & 1 & 0.031 & 1.856 \\
\hline Single - men & 0.369 & 0.135 & 7.514 & 1 & 0.006 & 1.446 \\
\hline Single - women & 0.465 & 0.131 & 12.646 & 1 & 0.000 & 1.592 \\
\hline \multicolumn{7}{|l|}{ Age of head under 34 - ref. } \\
\hline Age of head 35-49 & -0.847 & 0.084 & 102.355 & 1 & 0.000 & 0.429 \\
\hline Age of head 50-64 & -1.760 & 0.102 & 300.191 & 1 & 0.000 & 0.172 \\
\hline Age of head 65 and over & -1.918 & 0.169 & 129.469 & 1 & 0.000 & 0.147 \\
\hline Size of household & -0.346 & 0.048 & 52.654 & 1 & 0.000 & 0.708 \\
\hline \multicolumn{7}{|l|}{ Lower-level employee - ref. } \\
\hline Self-employed & 0.059 & 0.116 & 0.261 & 1 & 0.609 & 1.061 \\
\hline Higher-level employee & 0.065 & 0.088 & 0.548 & 1 & 0.459 & 1.067 \\
\hline $\begin{array}{l}\text { Pensioner with EA household } \\
\text { members }\end{array}$ & -0.426 & 0.270 & 2.489 & 1 & 0.115 & 0.653 \\
\hline $\begin{array}{l}\text { Pensioner without EA household } \\
\text { members }\end{array}$ & -0.509 & 0.158 & 10.410 & 1 & 0.001 & 0.601 \\
\hline Unemployed & 1.060 & 0.153 & 47.970 & 1 & 0.000 & 2.886 \\
\hline Others & 0.873 & 0.194 & 20.194 & 1 & 0.000 & 2.393 \\
\hline Constant & -0.352 & 0.188 & 3.529 & 1 & 0.060 & 0.703 \\
\hline
\end{tabular}

Source: Authors' computation, EU-SILC 2007-2008.

The results of Model III confirm that the main factor explaining the differences in the social structure of tenants in market private rental housing and the social structure of homeowners is above all the age of the head of the household, followed by income, household size, and the occupational status of the head of the household. The PRS tenant is 'typically' associated with a lower occupational category or with unemployment, low per capita income, young age, single, and 
Figure 1. Housing satisfaction according to tenure (scale: 1 - very satisfied, 10 - very dissatisfied)

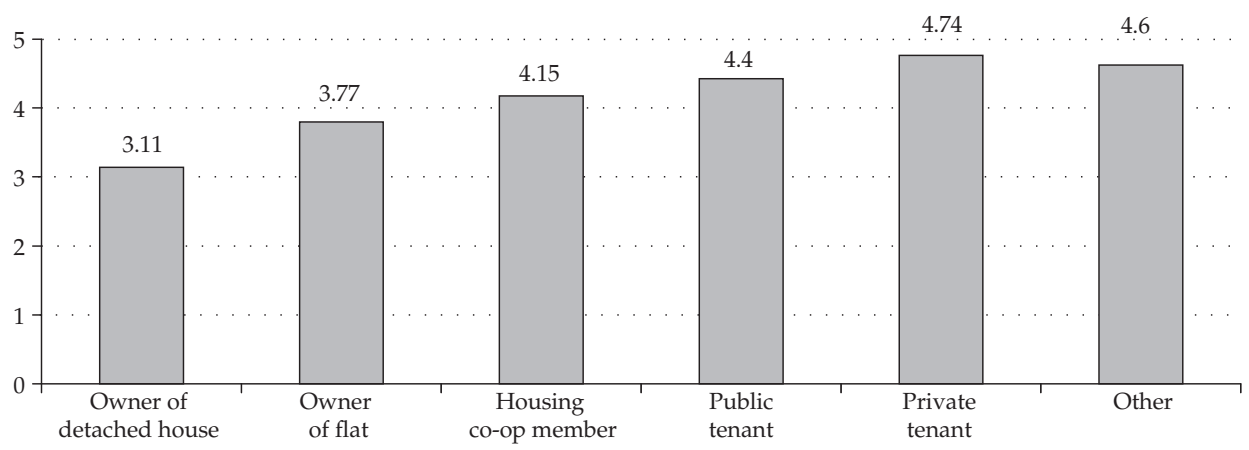

Source: Housing Attitudes in the Czech Republic 2001, N = 3.534

Notes: The question read: 'If you had to assess how satisfied you are on the whole with your housing, how would you rate your satisfaction? Use a ranking from 1 to 10 , where 1 means very satisfied and 10 means you are very dissatisfied.'

small-sized households. The PRS dwelling is 'typically' associated with high costs (see the contradiction with the low income of tenants!), a small number of rooms, a low technical standard (problems with humidity, insufficient light or external noise), and a location in the less developed Czech regions. The results of tenure choice models, though with low fit statistics, showed that the PRS in the Czech Republic acquired more the character of transitional and residual housing than of a stable, life-long housing alternative to owner-occupation.

This finding has also been confirmed by attitude surveys. The PRS came to be regarded as a temporary and residual form of housing by tenants themselves. The results of a large-scale housing attitude survey of the Czech population called Housing Attitudes 2001, carried out by the Socioeconomics of Housing research team at the Institute of Sociology AS CR on a representative sample of the Czech population in 2001 (sample 3500 respondents), revealed that housing satisfaction is largely influenced by housing tenure: housing in a rental flat from a private owner was associated with the lowest satisfaction rate (Figure 1). Another question in the same survey asked respondents whether they regard their current housing as ideal or not; only $37 \%$ of the PRS tenants considered their housing ideal, compared to $83 \%$ of detached house-owners and $53 \%$ of flat-owners. Of those respondents who were planning to move out of their current housing within the next three years the largest share was recorded among PRS tenants (30\%), compared to $6 \%$ of owners of detached houses and $11 \%$ of flat-owners.

The additional sociological survey also discovered that new norms relating to private tenancy became deeply rooted in society. A partial answer to the question whether preferences might change if the tenant protection in the market segment of the PRS increased is provided by the results of a small telephone sur- 
vey of first-time homebuyers in Prague, that is, among people who bought their first flat in Prague in 2007. The survey was conducted by telephone interview on a sample of 150 respondents. The majority of the respondents were selected 'randomly' on the basis of a contact obtained for them from their advertisements looking to buy a flat in Prague. The largest share of respondents were tenants at the time: $59 \%$ of the respondents $(41 \%$ were tenants in a flat with market rent and $18 \%$ were tenants in a flat with regulated rent); $24 \%$ of the respondents lived with their parents or other relatives and 15\% were private subtenants. It is worth noting that for a large number of first-time homebuyers, living in a rental flat was not just a short-term temporary arrangement: only one-quarter of respondentstenants had been living as a tenant for less than five years, while one-half of them had been tenants for more than 15 years. Given the size of the sample and the method used to select the respondents it was impossible to guarantee the representativeness of the entire target population.

The responses to the question of why people buy their own flat and why they do not rent it instead were relatively straightforward. Respondents were not given a list of responses to choose from, but rather were asked to answer both of these questions in their own words. While their answers differed in terms of how they were formulated, in every case they basically emphasised the following advantages of homeownership: buying a flat is a good investment, so it is better to pay the instalments on a loan than it is to pay a rent. Flat ownership was also valued for the sense of security that is associated with it, which was contrasted with the insecurity of being a tenant in rental housing and with negative personal experiences with landlords. Some respondents indicated, without any further specifications, that they simply want to live in their own home. All these reasons point to a deep conviction that it is better to own than to rent the housing you live in. By all appearances this conviction is not a response to a momentary situation in the market - it was rare to hear arguments like 'right now it's easy to get a mortgage and get it on good terms' or 'I just happen to have the money now make the purchase'.

This research attempted to determine what might eventually tempt respondents away from their decision to buy a flat. They were presented with a battery of questions that described different possible situations and they were asked whether were such a situation to occur they would consider renting instead of buying a flat. The responses are summarised in Figure 2. They clearly show that the respondents were not easily deterred from their conviction that buying a flat is the right decision. More than one-half of the respondents remained unmoved by all of the potential situations. Relatively the largest obstacle was seen as the situation where they are at risk of losing their job; being undecided about whether they would stay in Prague or not was also considered a significant obstacle. Finally, more than one-quarter of respondents would be deterred from buying a flat if flat prices were too high and at risk of falling - this is something that, contrary to real subsequent development, they did not believe to be the situation. 
Figure 2. Share of first-time housing-buyers who in the given situation would consider renting instead of buying a flat

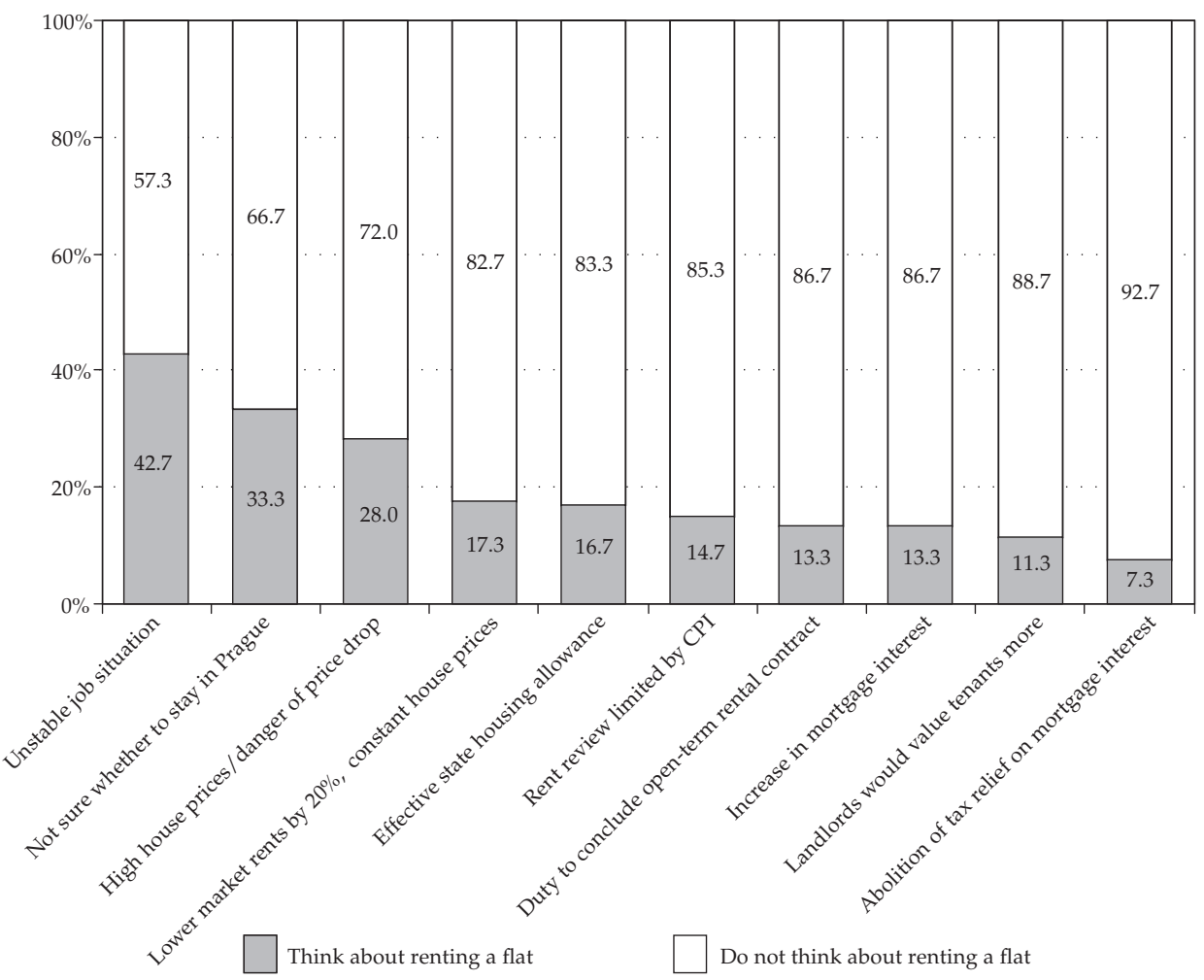

Source: Attitudes of First-Time Home-Buyers to the Trend in the Housing Market in Prague 2007, N = 150 .

Notes: The question read: 'You decided to buy a flat. What circumstances might lead you to reconsider your decision and rent a flat instead of buying one? I'll present several possible circumstances that could occur and for each one please indicate whether under such a circumstance you would consider renting instead of buying a flat.'

It is significant that no change, not even a very fundamental one, in the segment of rental housing, would in respondents' views be sufficient to alter their preference to own their housing. A decrease in the level of market rent by $20 \%$ or the introduction of a more effective housing allowance would plant a 'seed of doubt' $^{\prime}$ in the minds of just $17 \%$ of the respondents, a cap on market rent increases would change the mind of just $15 \%$ of them, the introduction of the requirement to sign open-term leases just $13 \%$ of them, and the fact of landlords valuing their tenants more over $11 \%$ of them. The general conviction that clearly the more advantageous decision is to invest in housing ownership, which at least in the short 
term of the recent past, but also in the current outlook to a more uncertain future was not supported by relevant information, emotionally prevailed over any rational decision-making among those looking for long-term housing.

\section{Conclusion}

Though the social structure of occupants of competing housing tenures (the PRS and owner-occupied housing) is far less different than the dwelling characteristics, the shift in the meaning and role of rental housing after 1990 is obvious - away from life-long public housing tenure towards residual and transitional private rental housing. Like in those advanced countries where a more dramatic form of rent liberalisation occurred (UK, Ireland, Belgium, Finland), in the Czech Republic the significance of rental housing quickly changed to become a temporary and residual form of housing. This change has been confirmed both by logit models and the results of attitude surveys. The German specific type of policy, which may be viewed as traditionally close to the Czech cultural environment, and which would also more logically reflect the status of rental housing before 1990, was entirely abandoned.

This dramatic change in social norms and consequently in the form of housing system has probably been caused by the specific state interventions in the area of property restitution, rent regulation, and the protection of tenant rights; especially owing to the lack of protection attached to lease durations and the uncertainty attached to rent reviews in the 'non-privileged' segment of the PRS. The quick increase in the supply of private renting was accompanied by the quick structural changes in the demand for rental housing generally. The conditions unilaterally supporting the quick supply of new private rental dwellings on the market at the same time constrained the long-term demand for them. The policy that favoured strict rental housing segmentation (the different conditions and rules in the 'privileged' and the 'non-privileged' rental segments) instead of reforming the general rules of the game (introduction of a second-generation rent regime and new universally applied tenant protection rules) is very probably, after taking into account the features of the general context of the 1990s, the main reason why nowadays the PRS is perceived only as a residual and transitional form of housing.

Neither the older generation nor younger people influenced by their value patterns could accept such a sharp fall in tenure security in the field of rental housing - from low-rent 'quasi-ownership' to a free-market, legally almost unprotected environment. The entrance to owner-occupied housing came to be viewed as the only way of securing long-term housing. This imperative is so firmly and emotionally embedded in people's views that even a substantial improvement in the affordability of market PRS, making rental housing relative to owner-occupation financially a more rational tenure option, had almost no effect on real tenure 
choice. The strong imperative to own one's housing has been confirmed by other surveys and market experiments not mentioned here [Lux et al. 2008].

This altered perception of the meaning of rental housing became a widely accepted social norm. As the telephone survey results showed, if instead of heading towards a liberal system of second-generation rent regulation the Czech Republic were to move - as the international comparison reveals - towards a less segmented, moderate system of second-generation rent regulation, the stabilisation of private rental housing would probably take a long time. Even if housing policy is more balanced in the future, it is to be expected that it will take a long time before these norms can be turned around.

These conclusions also show that Kemeny's typology of housing systems (policies) miss important contextual aspects, which detracts from the ability of his typology to analyse the meaning of the PRS in different societies. The inability of his typology to reflect the differences between rental policies within the group of countries with, what he calls, a 'unitary' housing policy, for example between the rental policies of Germany and Denmark, make it unhelpful for answering the question of why the meaning of the PRS varies. Instead we showed that the type of regulation applied to the PRS, and especially the type of rent regulation, may be of crucial importance. This aspect thus should be incorporated in any comparative housing system typology, especially when this typology also has to reflect important differences in the intrinsic meanings ascribed to rental housing in different social environments.

MARTIN Lux is head of the Department of Socioeconomics of Housing at the Institute of Sociology, Academy of Sciences of the Czech Republic. He has run several national and international housing research projects in the field of housing economics, housing finance and housing policies.

Petr SUNEGA is a member of the Department of Socioeconomics of Housing at the Institute of Sociology, Academy of Sciences of the Czech Republic. His field of specialisation is housing allowance in comparative perspective, housing economics, and market simulations.

\section{References}

Arnott, R. 1995. 'Time for Revisionism on Rent Control?' Journal of Economic Perspectives 9: 99-120.

Barlow, J. and S. Duncan. 1994. Success and Failure in Housing Provision. European Systems Compared. Oxford: Pergamon.

Berger, P. L. and T. Luckmann. 1966. The Social Construction of Reality: a Treatise in the Sociology of Knowledge. Garden City, NY: Anchor Books.

Boelhouwer, P. J. and H. M. H. van der Heijden. 1992. Housing Systems in Europe. Delft: Delft University Press.

Boelhouwer, P. J. and H. M. H. van der Heijden. 1993. ‘Housing Policy in Seven European 
Countries: the Role of Politics in Housing.' Journal of Housing and the Built Environment 8: 383-404.

Donner, C. 2000. Housing Policies in the European Union. Vienna: s.n.

Donner, C. 2006. Housing Policies in Central Eastern Europe. Vienna: s.n.

Dübel, A. 2003. Housing Policy in Central European Countries in Transition. Vienna: Center of Legal Competence.

Filer, K. R. 1995. ‘Reforma trhu s byty v České republice: Pokrok a zbývající úkoly' (Reform of the Housing Market in the Czech Republic: Progress and Remaining Tasks). Pp. 23-42 in Liberalizace trhu s byty v České republice. Prague: Aleko.

Ford, J., J. Rugg and R. Burrows. 2002. 'Conceptualising the Contemporary Role of Housing in the Transition to Adult Life in England.' Urban Studies 39: 2455-2467.

Giorgi, L., A. Kofler and D. Avramov. 2001. 'European Housing Policies Compared.' ICCR Working Papers No. 507. Vienna: ICCR.

Haffner, M., M. Elsinga and J. Hoekstra. 2008. 'Rent Regulation: the Balance between Private Landlords and Tenants in Six European Countries.' European Journal of Housing Policy 8: 217-233.

Haffner, M., J. Hoekstra, M. Oxley and H. M. H. van der Heijden. 2009. Bridging the Gap between Social and Market Rental Housing in Six European Countries? Amsterdam: IOS Press.

Hegedüs, J. and I. Tosics. 1998. 'Rent Reform - Issues for Countries of Eastern Europe and the Newly Independent States.' Housing Studies 13: 657-658.

Hughes, D. and S. Lowe (eds.). 2002. The Private Rented Sector in a New Century. Bristol: Policy Press.

Hughes, D. and S. Lowe (eds.). 2007. The Private Rented Housing Market. Aldershot: Ashgate.

Kemeny, J. 1981. The Myth of Homeownership. London: Routledge.

Kemeny, J. 1992. Housing and Social Theory. London, New York: Routledge.

Kemeny, J. 1995. From Public Housing to the Social Market. London: Routledge.

Kemp, P. A. (ed.) 2007. Housing Allowances in Comparative Perspective. Bristol: Policy Press.

Kratoška, J. 1920. Ochrana nájemníků : zabírání bytů, omezení práva stěhovacího. Výklad zákona (Tenant Protection: Occupation of Flats, Restrictions on Mobility Law. Statutory Interpretation). Prague: Ústřední dělnické knihkupectví a nakladatelství.

Lind, H. 2001. 'Rent Regulation: a Conceptual and Comparative Analysis.' European Journal of Housing Policy 1: 41-57.

Lowe, S. and S. Tsenkova (eds.). 2003. Housing Change in East and Central Europe: Integration or Fragmentation? London, New York: Ashgate.

Lundqvist, L. 1992. Dislodging the Welfare State? Housing and Privatisation in Four European Countries. Delft: Delft University Press.

Lux, M. (ed.) 2003. Housing Policy - an End or a New Beginning. Budapest: LGI/OSI.

Lux, M. 2009. Housing Policy and Housing Finance in the Czech Republic during Transition. An Example of Schism between the Still-living Past and the Need of Reform. Amsterdam: Delft University Press.

Lux, M., P. Sunega, M. Mikeszová and T. Kostelecký. 2008. Standardy bydlení 2007/2008. Faktory vysokých cen vlastnického bydlení v Praze (Housing Standards 2007/2008: the Factors behind High House Prices in Prague). Prague: Sociologický ústav AV ČR.

Mildschuh, V., R. Dušek and K. Herman. 1931. K naší otázce bytové (On the Czech Housing Question). Prague: Prometheus.

Oxley, M. and J. Smith. 1996. Housing Policy and Rented Housing in Europe. London: Chapman and Hall. 
Poláková, O. 2006. 'Historie bydlení a bytové politiky na území České Republiky' (The History of Housing and Housing Policy in the Czech Republic). Pp. 243-263 in Bydlení a bytová politika, edited by O. Poláková. Prague: Ekopress.

Rugg, J. (ed.) 1999. Young People, Housing and Social Policy. London, New York: Routledge.

Rugg, J. and D. Rhodes. 2008. The Private Rented Sector: Its Contribution and Potential. York: Centre for Housing Policy.

Šmídová, O. 1996. 'Vlastnictví a kvazi-vlastnictví bytů za socialismu a jejich postsocialistická mutace' (Ownership and Quasi-ownership under Socialism and Their Post-socialist Mutations). Pp. 115-136 in Provodní a noví vlastníci: strategie nabýváni majetku ve střední a východní Evropě, edited by A. Olivier and M. Tuček. Prague: CEFRES.

Struyk, R. (ed.) 1996. Economic Restructuring of the Former Soviet Block: the Case of Housing. Washington, DC: The Urban Institute Press.

Sýkora, L. and I. Šimoníčková. 1994. 'From Totalitarian Urban Managerialism to a Liberalized Real Estate Market: Prague's Transformations in the Early 1990s.' Pp. 47-72 in Development and Administration of Prague, edited by M. Barlow, P. Dostál and M. Hampl. Amsterdam: University of Amsterdam. 